\title{
Solid State Storage of Radioactive Krypton in a Silica Matrix
}

\author{
G. L. Tingey \\ J. M. Lytle \\ W. J. Gray \\ K. R. Wheeler
}

December 1980

Prepared for the U.S. Department of Energy under Contract DE-AC06-76RLO 1830

Pacific Northwest Laboratory

Operated for the U.S. Department of Energy

by Battelle Memorial Institute 


\title{
NOTICE
}

This report was prepared as an account of work sponsored by the United States Government. Neither the United States nor the Department of Energy, nor any of their employees. nor any of their contractors, subcontractors. or their employees, makes any warranty, express or implied. or assumes any legal liability or responsibility for the accuracy, completeness or usefulness of any information, apparatus, product or process disclosed, or represents that its use would not infringe privately owned rights.

The views, opinions and conclusions contained in this report are those of the contractor and do not necessarily represent those of the United States Government or the United States Department of Energy.

\author{
PACIFIC NORTHWEST LABORATORY \\ operated by \\ BATTELLE \\ for the \\ UNITED STATES DEPARTMENT OF ENERGY \\ Under Contract DE-AC06-76RLO 1830
}
Printed in the United States of America Available from
National Technical Information Service United States Department of Commerce 5285 Port Royal Road
Springfieid, Virginia 22151

Price: Printed Copy $\$$ $\therefore$ Microfiche $\$ 3.00$

$\begin{array}{cc}\text { •Pages } & \begin{array}{c}\text { NTIS } \\ \text { Selling Pric }\end{array} \\ 001-025 & \$ 4.00 \\ 026-050 & \$ 4.50 \\ 051-075 & \$ 5.25 \\ 076-100 & \$ 6.00 \\ 101-125 & \$ 6.50 \\ 126-150 & \$ 7.25 \\ 151-175 & \$ 8.00 \\ 176-200 & \$ 9.00 \\ 201-225 & \$ 9.25 \\ 226-250 & \$ 9.50 \\ 251-275 & \$ 10.75 \\ 276-300 & \$ 11.00 \\ & \end{array}$




\section{7}

\section{SOLID STATE STORAGE OF RADIOACTIVE} KRYPTON IN A SILICA MATRIX
G. L. Tingey
J. M. Lytle
W. J. Gray
K. R. Wheeler

December 1980

Prepared for the U.S. Department of Energy under Contract DE-AC06-76RLO 1830

Pacific Northwest Laboratory

Richland, Washington 99352 
$\checkmark$ 


\section{SUMMARY}

The feasibility of loading a low density $\mathrm{SiO}_{2}$ glass with krypton for storage of radioactive $\mathrm{Kr}-85$ has been demonstrated by studies using nonradioactive krypton. A $96 \% \mathrm{SiO}_{2}$ glass with $28 \%$ porosity was heated at an elevated pressure of $\mathrm{Kr}$ gas to a temperature of $850-900^{\circ} \mathrm{C}$ and held at that temperature to sinter the glass-krypton composite to a density of about $2 \mathrm{~g} / \mathrm{cm}^{3}$. A krypton content of $30 \mathrm{~cm}^{3}$ of $\mathrm{Kr}(\mathrm{STP}) / \mathrm{cm}^{3}$ of $\mathrm{glass}$ has been demonstrated when loading pressures of $140 \mathrm{MPa}$ are used.

Krypton release rates from the glass are lower than reported for any other waste form considered currently. At $420^{\circ} \mathrm{C}$ a diffusion parameter, $D / r_{0}^{2}$, of $8.66 \times 10^{-13} \mathrm{~min}^{-1}$ was determined which leads to a total release of $0.7 \%$ of the krypton in 10 years. Release rates increase moderately with increasing temperature up to $600^{\circ} \mathrm{C}$ and increase rapidly above $600^{\circ} \mathrm{C}$. The release of krypton from the loaded glass is accompanied by devitrification, comminution, and softening at temperatures above $600^{\circ} \mathrm{C}$. The lower loading pressures (about $40 \mathrm{MPa}$ ) may appear to yield a more favorable product from the point of view of krypton release than the high pressures. Advantages and disadvantages of the technique are given in the conclusions section. 


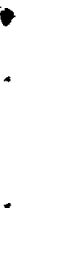




\section{CONTENTS}

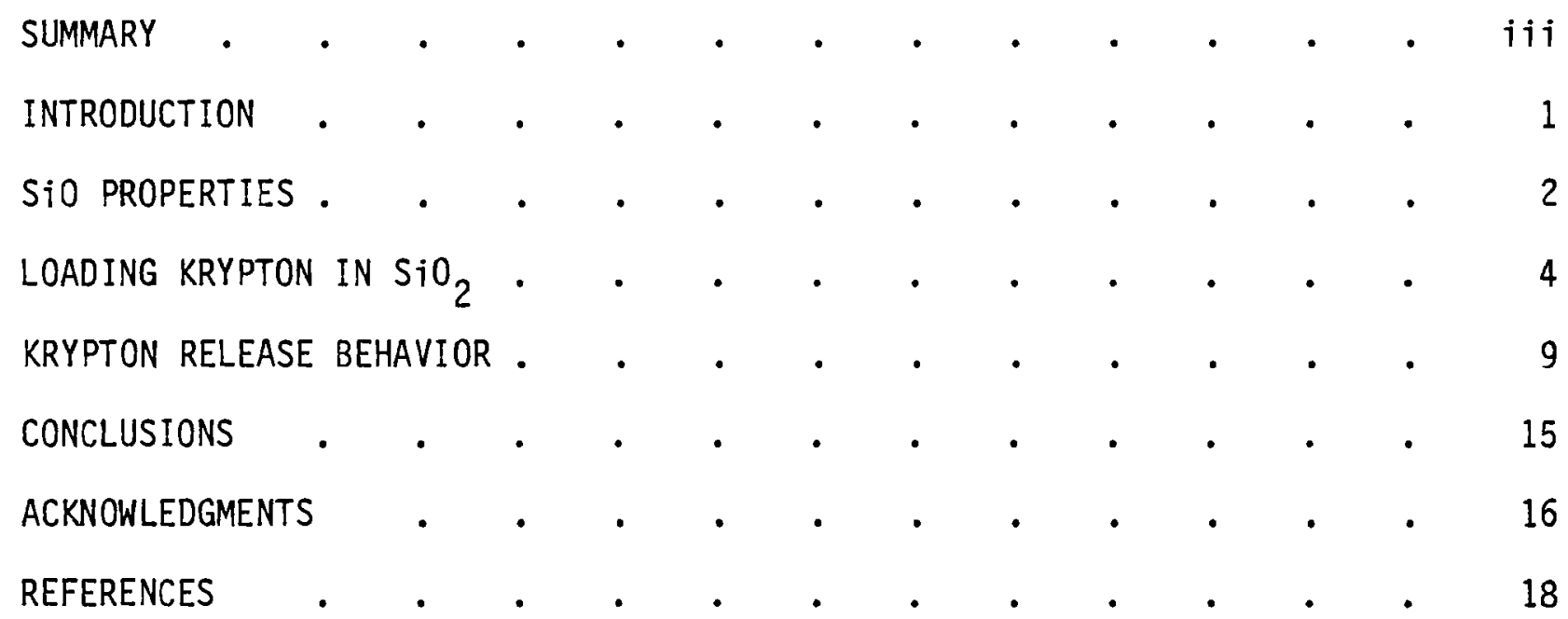




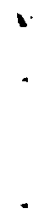

$\uparrow$ 


\section{INTRODUCTION}

Nuclear reactors used for electrical power production generate a large variety of radioactive fission products which must be collected and stored to protect the environment. The vast majority of these fission products are chemically reactive and remain solid to relatively high temperatures. The chemical reactivity thus provides a means for converting the isotopes to stable forms suitable for waste storage. The inert fission products, however, pose different problems in nuclear waste storage because one cannot take advantage of chemical reactivity.

During the nuclear fission process, several inert gas species are generated, but most of these have very short radioactive half-lives and decay while they are still in the reactor system. Krypton-85 and Xenon-133, with half-lives of 10.73 years and 5.25 days respectively, are the only exceptions, and release to the atmosphere could have an impact on the environment. Xenon-133 decays to a very low level in a period of a few months and thus long-term storage is not necessary, but the krypton- 85 remains active for a century or more. Krypton-85 decays to the non-radioactive isotope rubidium-85, with release of $\beta$ particles with a maximum energy of $0.66 \mathrm{MeV}$ and a small $(0.43 \%) Y$ yield with an energy of $0.52 \mathrm{MeV}$. The chemical inertness of the isotope leads to minimized biological activity and increases its stability in the atmosphere. Because of the relatively long lifetime of krypton-85 in the environment, the Environmental Protection Agency has established a release 1 imit of $50,000 \mathrm{Ci}$ of krypton-85/ giga watt-year of electrical power generated (EPA, 1977). In order to meet this limit, several storage methods are being evaluated.

Storage in gas bottles is an obvious choice but concern for accidental release of large quantities of the gas has provided the incentive to develop methods where the krypton can be incorporated in stable solid matrices. Proposed solid storage methods include immobilization in the pores of molecular sieve materials, formation of inert gas clathrates, entrapment in vapor deposited metals, and ion implantation in sputter-deposited metals (Thamer, 1979). 
The purpose of this document is to report the feasibility of dissolving or trapping krypton in a porous silica glass. The dissolution or trapping occurs when the glass is subjected to krypton at high pressures. The material is then sintered at high temperature to markedly increase the diffusion path for escape of the gas.

The solubility of inert gases in various glass types has been a subject of interest for several years. Data obtained prior to 1973 are adequately reviewed by Shelby (1973). In general, the solubility of inert gases decreases with increasing molecular weight through the series $\mathrm{He}$, Ne, and $\mathrm{Ar}$, but little or no data are available for $\mathrm{Kr}$ and $\mathrm{Xe}$. One can, however, infer the solubility of $\mathrm{Kr}$ in $\mathrm{SiO}_{2}$ glasses from measurements of permeability and diffusivity in the literature (Perkins, 1971; Felix, 1974). In addition, Brandt $(1975,1977)$ has published a direct measurement of the solubility of $\mathrm{Kr}$ in vitreous silica. All of these data indicate that the solubility of $\mathrm{Kr}$ in glass at atmospheric pressure is extremely low, or alternatively that the permeability is so low that saturation is not achieved; thus, measurements of solubility are subject to large uncertainties. Furthermore, the solubility is undoubtedly a function of the physical and chemical properties of the glass and, thus, varies widely from one glass to another. In support of this, Doremus (1966) has shown that gas solubility is a function of the free volume in the glass. Because of these observations, we initiated an experimental investigation of the quantity of $\mathrm{Kr}$ which could be loaded in high surface area, high porosity $(\sim 30 \%) \mathrm{SiO}_{2}$ rods. Samples were selected which had very fine open pores so that the solid state diffusion path in the sample would be short. This diffusion path would then be increased by sintering the sample to prevent rapid escape of the gas. The results of these studies and the conclusions drawn form the basis of this document.

\section{$\underline{\mathrm{SiO}}_{2}$ PROPERTIES}

The glass used in these studies was Corning's Vycor brand thirsty glass obtained in rods of nominally $1.06 \mathrm{~cm}$ in diameter. A compilation of the composition and physical properties, as supplied by the manufacturer, is shown in Table 1. 
TABLE 1. Physical Properties and Composition of $\cdot V_{y c o r}{ }^{\circledast}$ Brand Thirsty Glass (Corning, 1964)

Composition: $\quad \mathrm{SiO}^{2}=96 \%$

$$
\begin{aligned}
\mathrm{B}_{2} \mathrm{O}_{2} & =3 \% \\
\mathrm{Na}_{2} \mathrm{O} & =0.4 \% \\
\mathrm{R}_{2} \mathrm{O}_{3}\left(\mathrm{RO}_{2}\right) & =1.0 \% \text { (R= Mostly } \mathrm{A} 1 \text { or } \mathrm{Zr} \text { ) }
\end{aligned}
$$

Physical Properties:

$$
\begin{aligned}
\text { Specific Gravity (dry) } & =1.5 \mathrm{~g} / \mathrm{cm}^{3} \\
\text { Void Space } & =28 \% \\
\text { Surface Area } & =250 \mathrm{~m}^{2} / \mathrm{g} \\
\text { Average Pore Diameter } & =40 \AA
\end{aligned}
$$

Since it was assumed that the sintering behavior of the glass would dictate the loading conditions, the rate of densification was determined using an Anter Laboratories, Unitherm Model 1611, dilatometer. Samples were placed in the dilatometer and heated in ambient air at a programmed rate of $4^{\circ} \mathrm{C} /$ minute while continuously monitoring the sample dimensions. Figure 1 shows the pore volume,

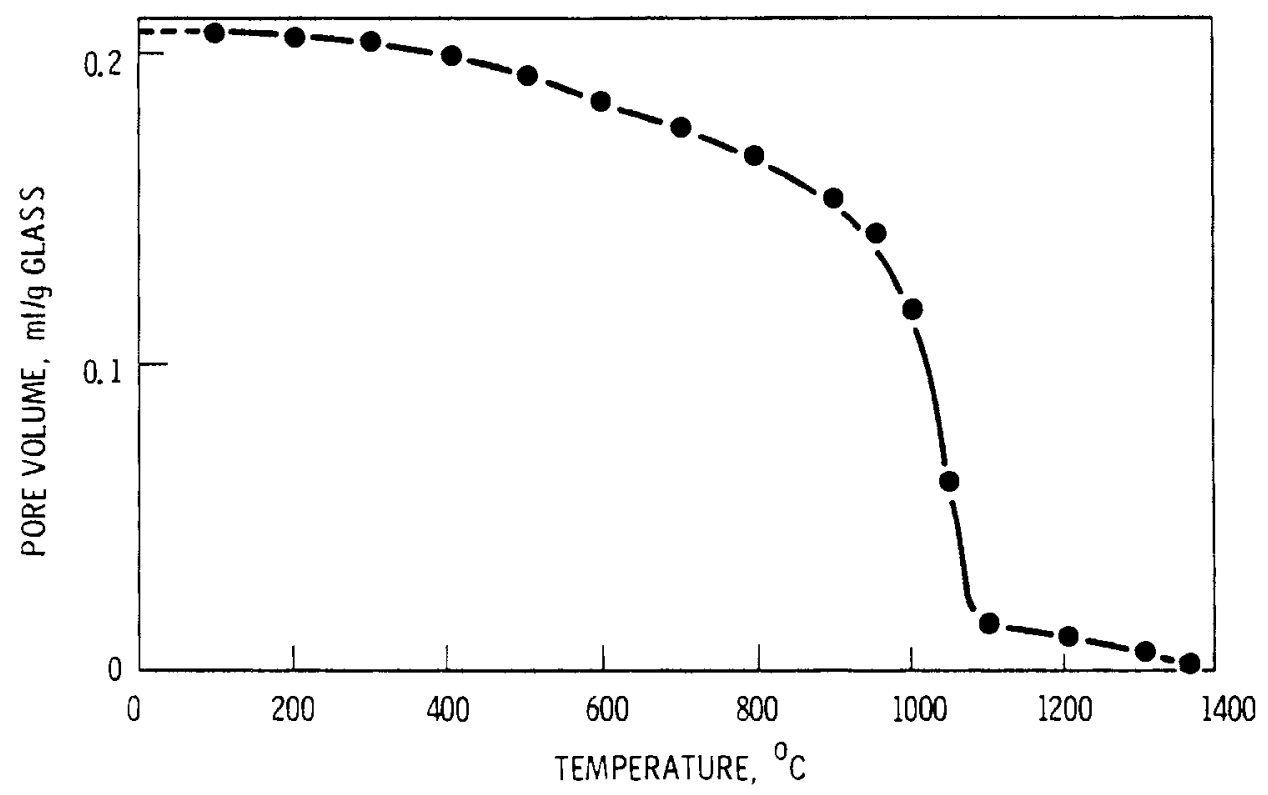

FIGURE 1. Pore Volume Versus Temperature for Thirsty Vycor ${ }^{\otimes}$ Glass Heated and Sintered in a Dilatometer at $4^{\circ} \mathrm{C} / \mathrm{min}$ and Ambient Pressure 
calculated from the measured dimensional changes assuming isotropic shrinkage, as a function of temperature. The densification rate is observable but quite low in the range from 200 to $900^{\circ} \mathrm{C}$ with a rapid increase in rate above $900^{\circ} \mathrm{C}$. Measurements of the dimensions before and after the heat treatment in high pressures of krypton yielded densification rates in reasonable agreement with the dilatometer studies.

\section{LOADING KRYPTON IN $\mathrm{SiO}_{2}$}

Samples were prepared for krypton loading by cutting the SiO rods to a length of about $1.3 \mathrm{~cm}$. In order to do this without fracture, it was necessary to saturate them with water prior to cutting with a diamond saw. After cutting, the samples were allowed to dry under ambient conditions for several days and then placed in a desiccator. In some instances the samples were further dried by heating to $150^{\circ} \mathrm{C}$ under vacuum. Attempts to dry more rapidly invariably fractured the samples or caused them to crack badly. By following the weight change of the samples during the drying process, we have shown that little or no drying occurs during the vacuum heat treatment after thorough desiccation.

For loading with krypton, the dried glass samples were placed in high pressure containers designed to withstand the pressure and temperature desired for the test. Most of the loading experiments were conducted in the temperature range of 700 to $900^{\circ} \mathrm{C}$ at pressures of about $40 \mathrm{MPa}$ in capsules shown schematically in Figure 2. For pressures in the range of 20 to $40 \mathrm{MPa}$ and temperature

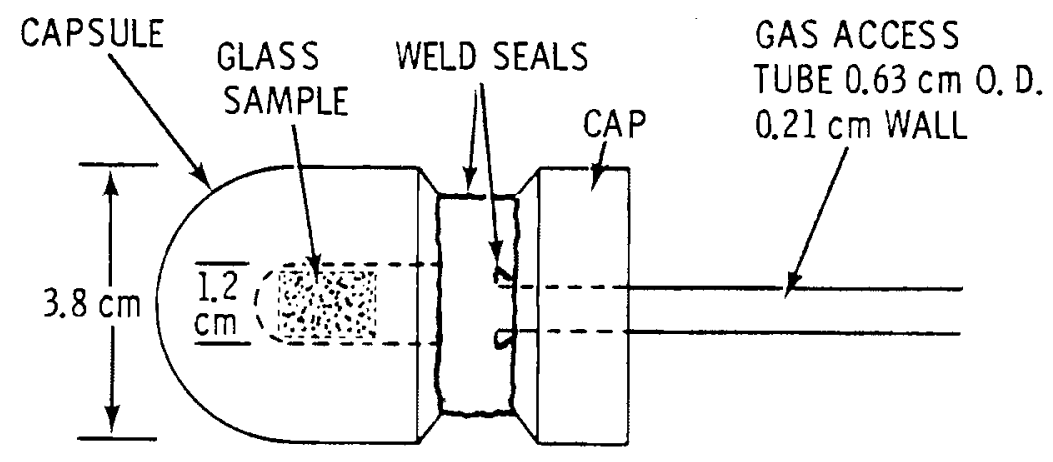

FIGURE 2. Capsule Used for Loading $\mathrm{Kr}$ into Porous Glass at High Temperatures and Pressures. Capsule and tube material are Inconel 600, welded with Inconel 82 filler rods. 
near $900^{\circ} \mathrm{C}$, welded construction was found necessary to minimize leaks. During the capsule welding process, monitored temperatures in the vicinity of the glass sample approached $550^{\circ} \mathrm{C}$ for short periods of time. Since the sintering rate is relatively slow at this temperature (see Figure 1), we have assumed that the welding did not produce a significant decrease in the ability of porous glass to trap krypton. The welded capsule was evacuated to approximately $10 \mathrm{~Pa}$, heated to about $100^{\circ} \mathrm{C}$, and outgassed overnight. Following outgassing, the capsule was charged with krypton gas to approximately $60 \%$ of the desired final pressure to accommodate gas expansion at temperature. To achieve a level specimen temperature, the Inconel capsule was encased in a closed graphite cylinder drilled to accept the pressure tube and the monitor and control thermocouples. The assembly was located in a tube furnace with the heated zone extending several centimeters beyond each end of the graphite cylinder. Temperature rise was programmed to reach the desired sintering temperature in four hours, after which the temperature was held constant for a pre-selected period. During both heat up and temperature hold periods, the krypton pressure was adjusted to maintain a desired level. At the conclusion of the sintering period, the furnace power was turned off and the system allowed to cool slowly while maintaining a high krypton pressure.

The dimensions of the krypton loaded samples were measured with a micrometer and weighed. Release rate and total krypton content were determined by heating the samples to $1300^{\circ} \mathrm{C}$ in vacuum and by measuring the krypton evolved using the apparatus and procedure described earlier (Tingey, 1979).

Figure 3 shows the krypton content contained in porous $\mathrm{SiO}_{2}$ samples as a function of loading pressure. The points on the curve are experimental data, but the lines are calculated assuming that the gas is all contained in the internal closed porosity. The two lines are calculated using MIT coefficients interpolated to a temperature of $900^{\circ} \mathrm{C}(1173 \mathrm{~K}$ ) from data at 1000 and $1500 \mathrm{~K}$ (Amdur, 1950; Beattie, 1961) and the equation of state,

$$
P V+R T\left[1+(B / V)+\left(C / N^{2}\right)+\left(D / V^{3}\right)\right]
$$




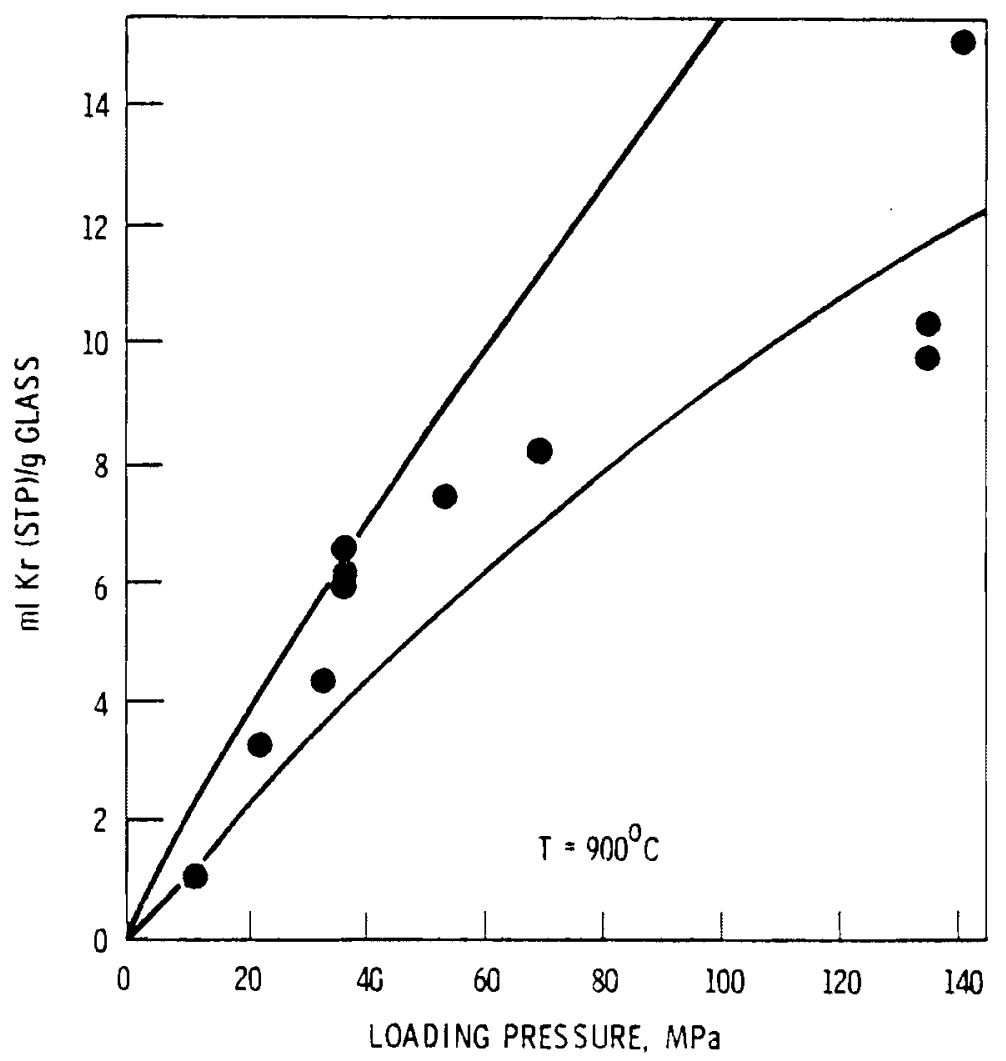

FIGURE 3. Quantity of Krypton Contained in Thirsty Vycor Glass as a Function of Loading Pressure. Points are experimentally measured and lines are calculated assuming all gas is trapped in the remaining porosity.

Values for the volume (V) were chosen to bracket the expected pore volume of sintered samples at 0.08 and $0.05 \mathrm{~cm}^{3} / \mathrm{g}$ of glass for the upper and lower lines, respectively. The total krypton content is nearly linear with pressure up to about $50 \mathrm{MPa}$ but deviates at higher pressures. All samples with loading pressures below $60 \mathrm{MPa}$ were loaded in the apparatus described. Those loaded at pressures above $60 \mathrm{MPa}$ were loaded in high pressure autoclaves at the Idaho Engineering Development Laboratory (INEL) at Idaho Falls, Idaho.

These relatively large krypton concentrations $\left(>15 \mathrm{~cm}^{3}\right.$ (STP)/g of glass) clearly demonstrate the feasibility of storing radioactive krypton in a glass matrix. With the density of the loaded glass approaching $2 \mathrm{~g} / \mathrm{cm}^{3}, a \mathrm{Kr}$ content of about $30 \mathrm{~cm}^{3}$ (STP) $/ \mathrm{cm}^{3}$ is calculated. This loading is adequate for storage of the fission product krypton from the nuclear fuel cycle. In fact, a somewhat lower loading [i.e., $14 \mathrm{~cm}^{3}(\mathrm{STP}) / \mathrm{cm}^{3}$ ], achievable at less than $40 \mathrm{MPa}$, may ultimately be selected to allow one to operate at the lower pressure. 
The krypton loading process is a combination of diffusion and/or permeation of the gas into the pores and perhaps the bulk of the glass. Sintering closes the porosity and markedly increases the diffusion distance required to release the gas. At present, the form of the krypton in the glass is not well known. It seems likely that krypton is both contained within the very small pores remaining after sintering and dissolved within the bulk. The ratio of the two remains undetermined, but since most of the points fall between the lines shown on Figure 3, it seems likely that most of the krypton is contained at elevated pressures in the small closed pores of the samples.

The time-temperature behavior of krypton diffusion or permeation and of glass sintering is not well understood. Measurements were, therefore, made to determine optimum conditions to maximize the $\mathrm{Kr}$ content of the glass sample without decreasing the retention. Figure 4 shows the krypton loading achieved as a function of time at temperature following a four hour heat up period. At $900^{\circ} \mathrm{C}$, the maximum loading was achieved when the sample was maintained for about five hours but decreased thereafter. With only 1 imited data available at $850^{\circ} \mathrm{C}$, it appears that in excess of five hours may be required to obtain the maximum loading with no evidence of a decrease up to 24 hours.

During heating, the glass sinters with an initial decrease in pore volume as shown on Figure 5 . The initial sintering appears to be essentially the same at 850 and $900^{\circ} \mathrm{C}$, both yielding a minimum pore volume of about 0.06 $\mathrm{cm}^{3} / \mathrm{g}$ of glass. Direct comparison of Figure 1 with Figure 5 is not possible because the heating rates are different, but it appears that the high pressures of krypton used in the tests shown in Figure 5 have little effect upon the initial sintering behavior of the glass.

At $900^{\circ} \mathrm{C}$, the glass samples shrink to a minimum volume and then expand. The expansion which occurs after about five hours may be caused by high internal pressures acting on the partially softened glass. The internal pressures result if the pores contract further after closing of if other gases such as $\mathrm{H}_{2} \mathrm{O}, \mathrm{CO}, \mathrm{CO}_{2}$, or $\mathrm{H}_{2}$ are desorbed. At $850^{\circ} \mathrm{C}$ no expansion is observed probably because of the higher viscosity of the glass. 


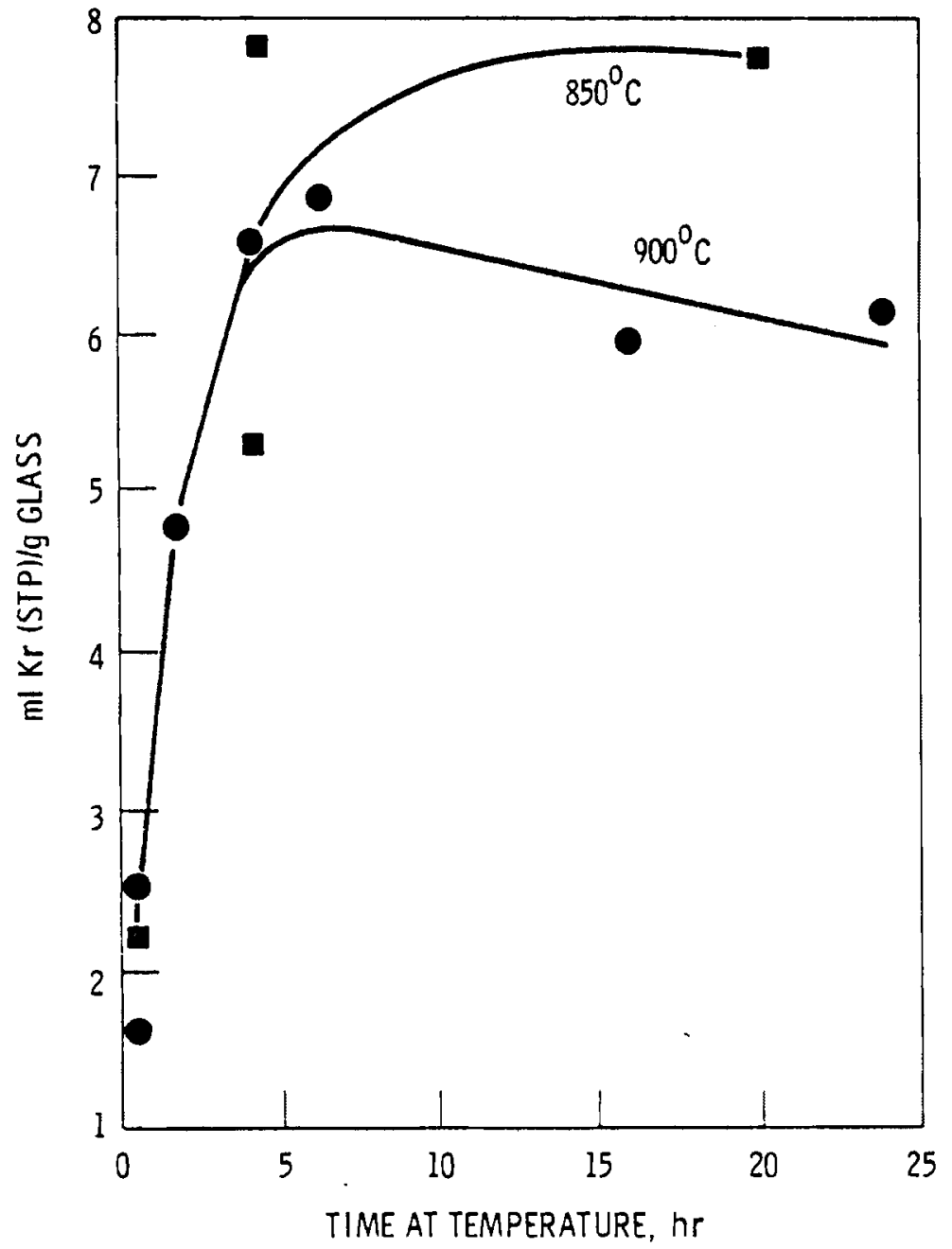

FIGURE 4. Volume of Trapped $\mathrm{Kr}$ Versus Time at Indicated Temperature and 34.9 - $37.3 \mathrm{MPa}$ Pressure for Thirsty Vycor ${ }^{\circledR}$ Glass

During the sintering process, the glass surface area also decreases markedly indicating the reduction or closing of the porosity. BET surface area measurements using $\mathrm{N}_{2}$ adsorption (Brunauer, 1938) on sintered samples yielded a surface area of $0.5 \mathrm{~m}^{2} / \mathrm{g}$ as compared to $100 \mathrm{~m}^{2} / \mathrm{g}$ obtained prior to krypton loading and sintering. This marked decrease in surface area clearly shows that the open pores are effectively closed. 


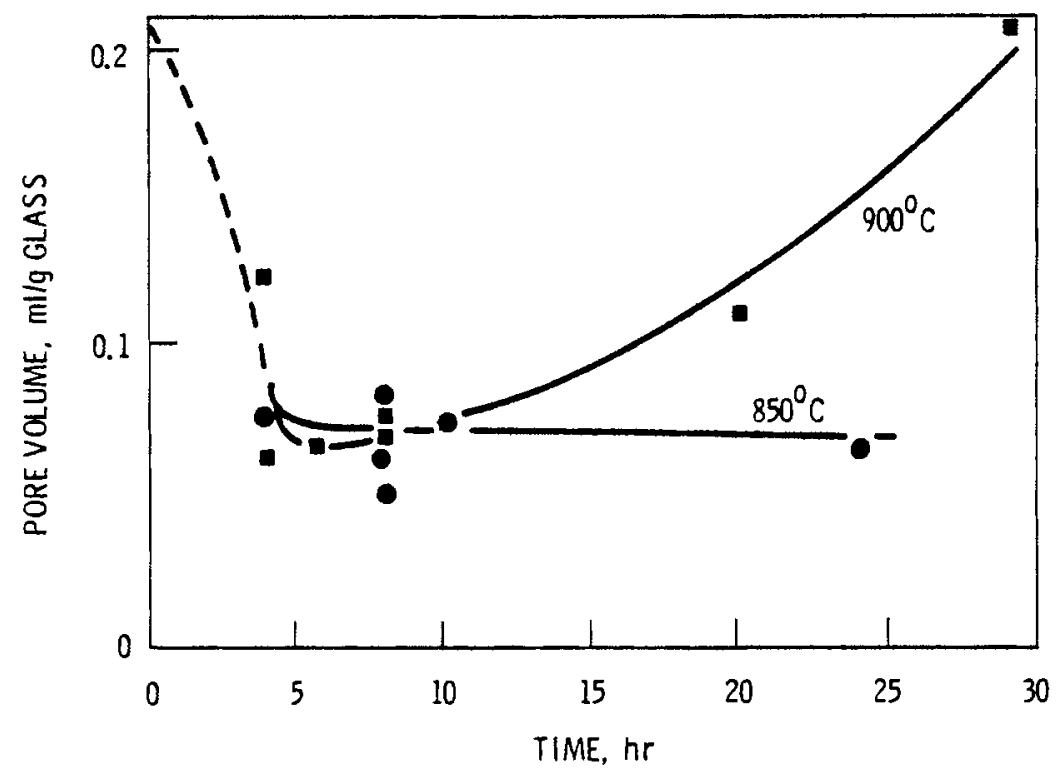

FIGURE 5. Pore Volume Versus Time for Thirsty Vycor ${ }^{\circledR}$ Glass Sintered in the Presence of $\mathrm{Kr}$ at $33-38 \mathrm{MPa}$ Pressure. The temperature is increased to $850^{\circ}$ or $900^{\circ} \mathrm{C}$ in $4 \mathrm{hr}$ and held at the indicated temperature for the remainder.

\section{KRYPTON RELEASE BEHAVIOR}

For the purpose of radioactive gas storage, the retention of krypton in the glass is the most important property. Therefore, considerable emphasis has been placed on the measurement of release rates of krypton as a function of temperature. Three types of measurements have been conducted as follows: (1) release of krypton as a function of temperature where the temperature is continuously increased at a rate of about $100^{\circ} \mathrm{C} /$ hour from ambient to $1300^{\circ} \mathrm{C}$, (2) isothermal release measurements in which samples were held at a constant temperature for periods from one hour to several days, and (3) long-term krypton measurements in which samples are held at $420^{\circ} \mathrm{C}$ for several months measuring the krypton released periodicaliy.

The first two types of measurements were made by heating the samples in an evacuated tube and measuring the quantity of gas collected by continuous Teoppler pumping. The resultant gases were then analyzed by gas chromatography to yield the krypton release rate. The equipment and technique for this method have been described earlier (Tingey, 1979). 
The long-term release measurements were made by sealing small krypton loaded samples in evacuated Pyrex ampoules and maintaining them at a temperature of $420^{\circ} \mathrm{C}$. At predetermined intervals, samples were removed and the gas admitted into a known, evacuated volume where the pressure was measured and the gas subsequently analyzed by gas chromatography.

The results of the temperature programmed release measurements are shown in Figure 6. In this figure, the log of the release rate, in units of percent of the original loading, is plotted as a function of temperature. Two separate experiments are plotted for comparison. Both samples were loaded with krypton at $900^{\circ} \mathrm{C}$ and held at this temperature for 90 minutes. One, however, was loaded with a $\mathrm{Kr}$ pressure of $33 \mathrm{MPa}$ while the other was loaded at $141 \mathrm{MPa}$. As depicted in Figure 6, the release curve is not well behaved. Apparently several processes are occurring during the release which tend to affect the release rate. At least three different temperature ranges are apparent, $400-700^{\circ} \mathrm{C}, 700-1000^{\circ} \mathrm{C}$, and $1000-1300^{\circ} \mathrm{C}$. At present experimental data are insufficient for a clear understanding of the mechanism of release. However, we have made several observations and postulates which are worthy of mention.

In the temperature region below $600^{\circ} \mathrm{C}$, release rates vary greatly with time during the early stages of release indicating the presence of very sma11, but measurable, quantities of krypton which are physically adsorbed on the surface or trapped very near the surface and thus are released very early in the programmed temperature experiments. More meaningful data in this temperature region are attained by long-term measurements.

In the temperature region from 700 to $1000^{\circ} \mathrm{C}$, the release appears to be a much more typical diffusion mechanism. An Arrhenius plot of the diffusion coefficient for this region has yielded an activation energy of about 20 $\mathrm{kcal} / \mathrm{mole}$ for a sample loaded at $34 \mathrm{MPa}$. Of greater concern is the increased krypton release rate of the sample loaded at a pressure of $141 \mathrm{MPa}$. Other samples loaded at pressures of about $140 \mathrm{MPa}$ invariably show a rate of krypton release one or two orders of magnitude greater than samples loaded at lower pressures. At present, the reason for these high rates has not been investigated. 


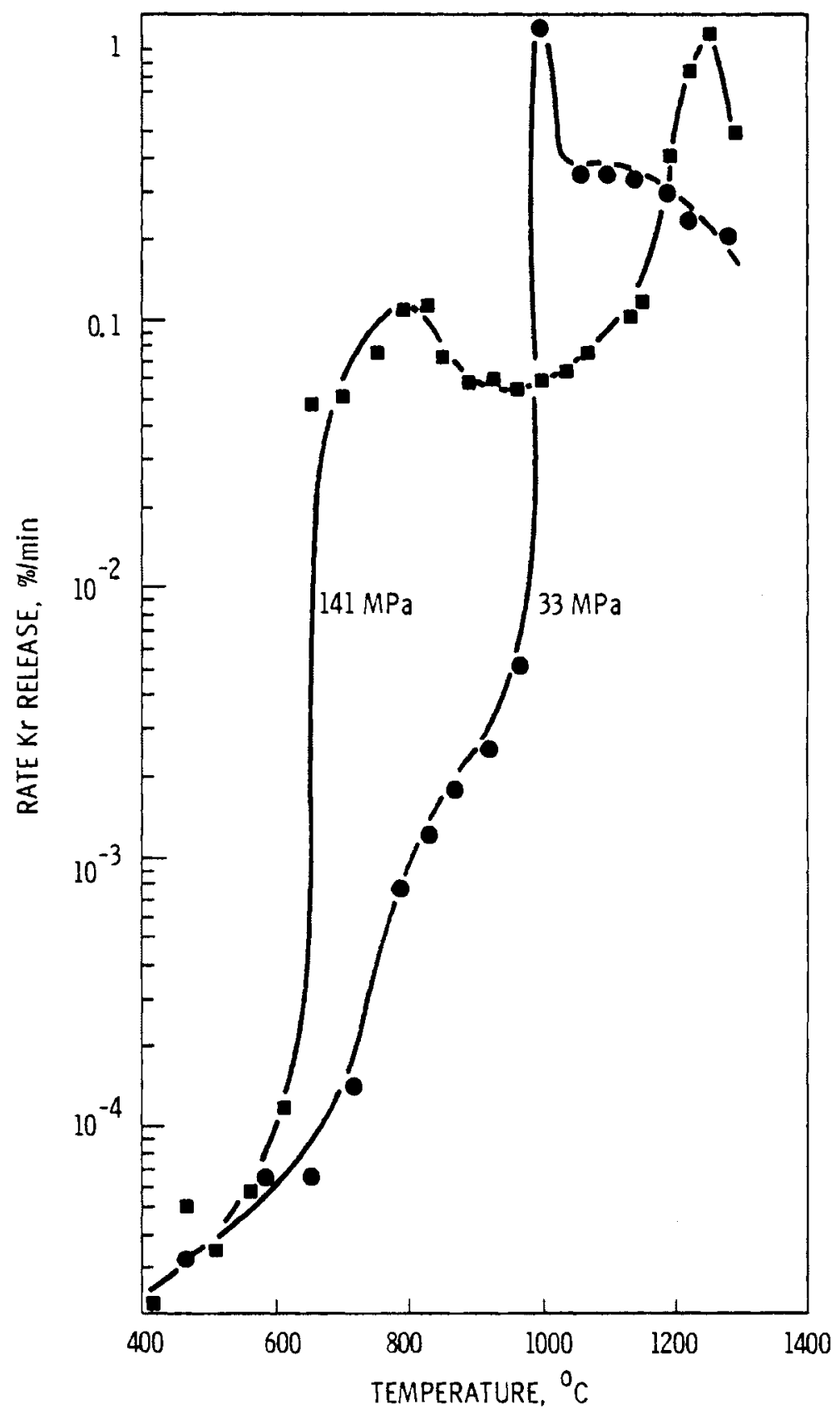

FIGURE 6. Rate of $\mathrm{Kr}$ Release Versus Release Temperature for Two Samples of Thirsty Vycor ${ }^{\otimes}$ Glass, Each Loaded and Sintered at $900^{\circ} \mathrm{C}$ for $1.5 \mathrm{hr}$ and the Indicated Pressure of $\mathrm{Kr}$. The release temperature was increased from 400 to $1290^{\circ} \mathrm{C}$ at $100^{\circ} \mathrm{C} / \mathrm{hr}$. 
In the transition temperature between this and the next region there is a marked increase in rate for the sample loaded at $33 \mathrm{MPa}$. We have interpreted this rate increase to be associated with a self comminution process which is always observed. In some cases the sample is stressed to the point where it breaks up to a powder. In other instances, the sample holds together but massive cracking is observed. We have postulated that this comminution decreases the diffusion path markedly and, thus, the release rate increases.

In the higher temperature region $\left(1000-1300^{\circ} \mathrm{C}\right)$, the release rates become very rapid. The Arrhenius plot of this region yields a somewhat higher activation energy ( $40 \mathrm{kcal} / \mathrm{mole}$ ) which is postulated to be due to diffusion from partially devitrified $\mathrm{SiO}_{2}$. Above about 1150 to $1200^{\circ} \mathrm{C}$, glass softening occurs producing major expansion or foaming of the sample.

Figure 7 shows the krypton release rates for long-term release at $420^{\circ} \mathrm{C}$ as a function of the square root of time from data collected for a period in excess of eight months. Although there is some scatter in the data, they appear to fall on a linear plot of release fraction versus square root of time as predicted from the equation: (Walker, 1966)

$$
F=\left(\frac{36 D t}{r_{0}^{2}}\right)^{1 / 2}
$$

where $F$ is the fraction of krypton released; $r_{0}$, the effective diffusion radius; $t$, time; and $D$, the diffusivity. This equation is accurate within $3 \%$ for values of $F<0.1$. It is strictly valid only for spherical geometry but holds with 1 imited deviations from spherical geometry if $r_{0}$ is appropriately defined (Walker, 1966). A calculation of $D / r_{0}{ }^{2}$ using equation 1 and the data in Figure 7 yields a value of $8.66 \times 10^{-13} \mathrm{~min}^{-1}$. Extrapolation of these data gives a total release fraction of $0.7 \%$ of the krypton after 10 years at $420^{\circ} \mathrm{C}$.

Figure 8 shows a similar plot of release fraction versus square root of time at a temperature of $808^{\circ} \mathrm{C}$, but the data are 1 imited to release measurements for 75 hours. We have calculated the value of $D / r_{0}{ }^{2}$ to be $6.33 \times 10^{-8}$ $\min ^{-1}$ at $808^{\circ} \mathrm{C}$. Thus, we estimate a release of $10 \%$ of the krypton in about ten days. 


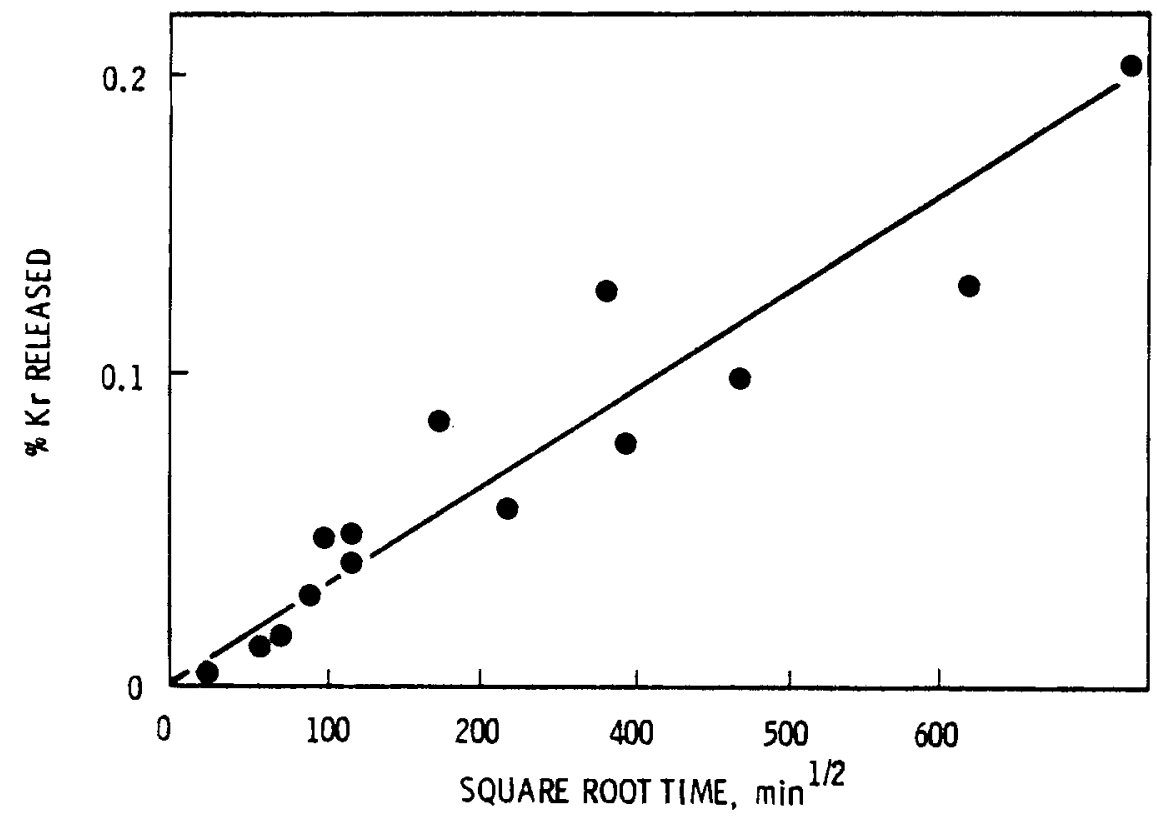

FIGURE 7. The Percent $\mathrm{Kr}$ Released Versus the Square Root of Time for Thirsty Vycor ${ }^{\otimes}$ Glass Loaded at $850^{\circ} \mathrm{C}$ and $35 \mathrm{MPa}$ with $\mathrm{Kr}$ Being Released Isotherma $17 y_{2}$ at $420^{\circ} \mathrm{C}$. The diffusion coefficient written as $D / r_{0}=8.66 \times 10^{-13} \mathrm{~min}^{-1}$.

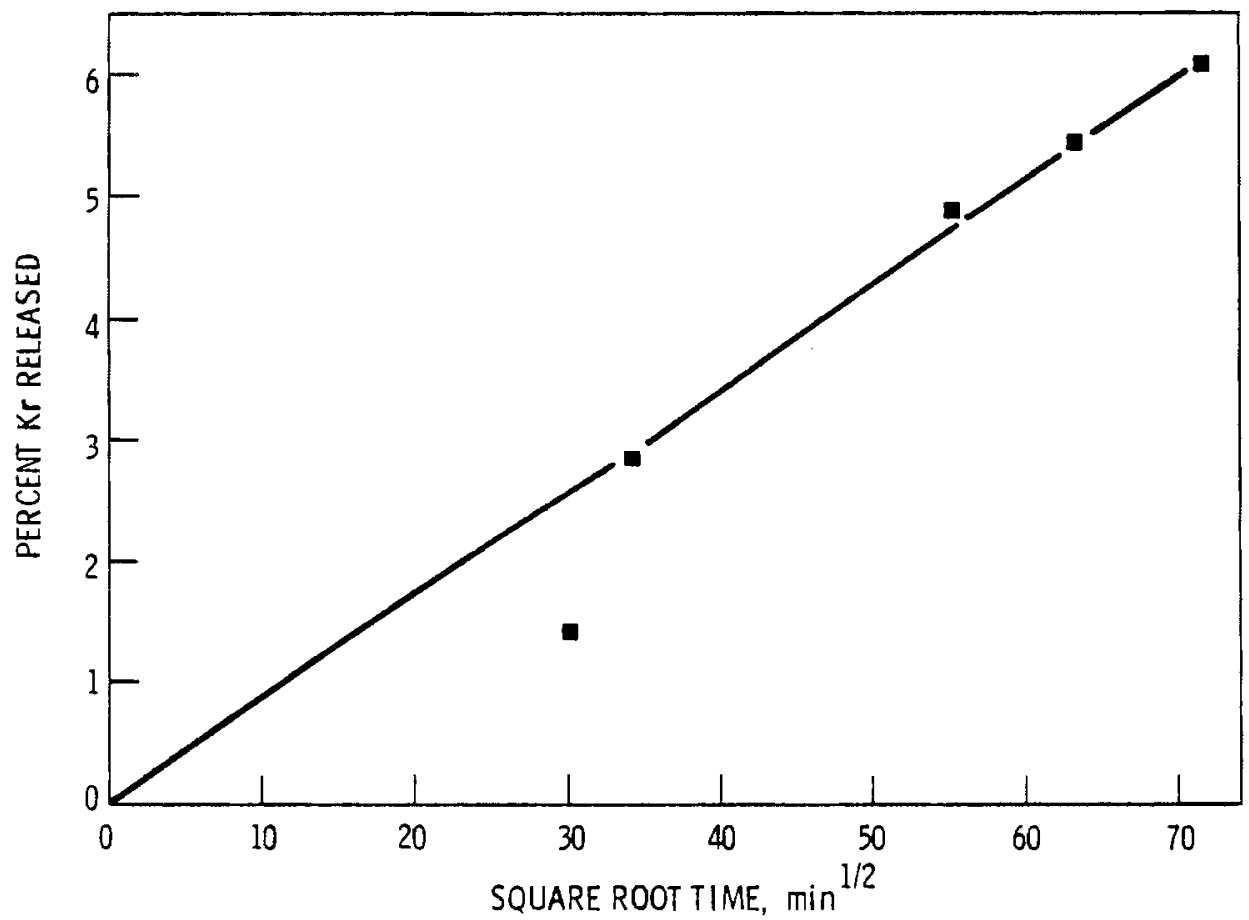

FIGURE 8. The Percent $\mathrm{Kr}$ Released Versus the Square Root of Time for Thirsty Vycor ${ }^{\circledR}$ Glass Loaded at $850^{\circ} \mathrm{C}$ and $96 \mathrm{MPa}$ with $\mathrm{Kr}$ Being Released Isothermally at $808^{\circ} \mathrm{C}$. The diffusion coefficient written as $D / r_{0}^{2}=6.33 \times 10^{-8} \mathrm{~min}^{-1}$. 
We have suggested that the release rates are decreased by sintering the glass. This phenomenon is illustrated by the data in Table 2 which shows the release rates for samples sintered at $900^{\circ} \mathrm{C}$ for a selected time. It is evident from these data that the sample which was heated to $900^{\circ} \mathrm{C}$ and then cooled without a temperature hold released krypton much more readily than those samples which were held at temperature for several hours. Further evidence of this phenomenon is shown in samples sintered at temperatures below $800^{\circ} \mathrm{C}$ yielding a sample in which the krypton was easily released.

At present the requirements for krypton retention in a solid matrix are not well defined, but it is evident that the release behavior of appropriately sintered low density $\mathrm{SiO}_{2}$ will exceed them by a large factor. In fact, this material appears to have the lowest krypton release rate of any of the solid state storage systems investigated to date.

TABLE 2. Release Rates of Krypton from Samples with Various Sintering Times

Hold Time

Uurina Loading at $900^{\circ} \mathrm{C}^{*}$

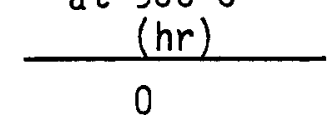

1.5

4

16

24

\begin{tabular}{cc}
\multicolumn{3}{r}{$\begin{array}{r}\text { Rate } \mathrm{Kr} \text { Releas } \\
\text { Temperatur }\end{array}$} \\
\cline { 1 - 1 }$\frac{600}{0.12}$ & $\frac{1.4}{1.4}$ \\
$2 \times 10^{-5}$ & $7 \times 10^{-5}$ \\
ni 1 & $\sim 1 \times 10^{-5}$ \\
$3.4 \times 10^{-5}$ & $\sim 10^{-5}$ \\
$\sim 10^{-6}$ & $\sim 10^{-5}$
\end{tabular}

$\begin{array}{ll}\frac{8}{\% / m i n} \\ \frac{800}{0.7} & \frac{1,000}{0.025} \\ 9 \times 10^{-4} & 1.2 \\ 9 \times 10^{-5} & 0.1 \\ 6 \times 10^{-4} & 0.015 \\ 1 \times 10^{-4} & 0.012\end{array}$

Internal PQ̧re

Volume, $\mathrm{cm}$ (0.208 before sintering)

0.122

0.067

0.069

0.110

0.208

*After 4 hour heat-up period 
CONCLUSIONS

Although the solubility of inert gases, specifically krypton, is apparently too low in fully dense glass for storage of radioactive krypton, relatively large quantities can be loaded in low density glasses. At present the form of the krypton is not well known, but is apparently either dissolved or trapped at high pressures in very small pores. In any case, the resultant krypton loaded glass is very stable and the krypton appears to be retained to higher temperature than any other waste form proposed to date, with rapid release occurring only at temperatures above $1000^{\circ} \mathrm{C}$ and with extremely low release rates at $420^{\circ} \mathrm{C}$.

It now appears that krypton loadings in excess of $15 \mathrm{~cm}^{3}$ (STP)/g of glass is achievable if pressures up to $140 \mathrm{MPa}$ are acceptable for handling large quantities of radioactive krypton. Loadings of $7 \mathrm{~cm}^{3}$ (STP)/g of glass $\left(14 \mathrm{~cm}^{3}(\mathrm{STP}) / \mathrm{cm}^{3}\right.$ of glass) have been demonstrated at a pressure of about 35 $\mathrm{MPa}$.

Low density glass has several advantages for storage of radioactive krypton. Among these are: (1) the ready availability of glass, (2) low potential for corrosion, and (3) high temperature stability. Disadvantages of this waste form are the brittle nature of the material and the low thermal conductivity. The major disadvantage, however, may prove to be the requirement to load the samples with relatively large inventories of $\mathrm{kr}-85$ at high pressures while sintering at high temperatures. This disadvantage appears to be common to all other candidate methods except that of ion implantation in sputter deposited metals (Tingey, 1979). A thorough analysis should, therefore, be made to determine the ability to license a process which handles large quantities of radioactive krypton under the high pressure, high temperature conditions.

For the process described in this document pressures below $40 \mathrm{MPa}$ now appear to be adequate and may yield a superior product from the standpoint of low temperature release. For low density high $\mathrm{SiO}_{2}$ glasses, temperatures of at least $850^{\circ} \mathrm{C}$ are required, but glasses that soften at lower temperatures 
are available and tests are currently underway that could reduce the sintering temperatures by 100 to $200^{\circ} \mathrm{C}$.

Further work is also required to optimize the process and to elucidate the form of the krypton in the glass and the mechanism of gas release. This work is underway and the results will be reported later.

\section{ACKNOWLEDGMENTS}

The authors gratefully acknowledge the U.S. Department of Energy, Office of Nuclear Waste Management, for financial support of this work. We are also grateful for the dedicated efforts of R. B. Watson for assistance in the high pressure loading of the glass, P. J. Raney for krypton release and other property measurement, and to Dr. D. A. Knecht and his associates at Exxon Nuclear Idaho Company for the loadings at pressures above $60 \mathrm{MPa}$. 


\section{REFERENCES}

Amdur, I. and E. A. Mosen. 1958. Phys. of Fluids. 1:370

Beattie, J. A. 1961. "Thermodynamic Properties of the Gas Phase." In Argon, Hel ium, and the Rare Gases, Vol. I, ed. G. A. Cook, p. 269. Interscience, New York.

Brandt, W. W. 1975. "Solubility and Diffusion Coefficients of Inert Gases in Inorganic Glasses, Comparison Based on Percolation Theory." Phys. Stat. Sol. (a) 30:163.

Brandt, W. W. and H.W. Ko. 1977. "Desorption of Krypton (or Krypton-85) and Sulfur Hexafluoride from Vitreous and Crystalline Silicon Dioxide and of Krypton from Boron Oxide and Germanium Oxide Glasses." In Reactivity of Solids, ed. by John Wood, p. 547. Plenum Press, New York.

Brunauer, S., P. H. Emmett, and E. Teller. 1938. J. Am. Chem. Soc. 60:309.

Corning. 1964. Communication Product Sales Department, J4.00 sheet 3 of 4.

Doremus, R. H. 1966. "Physical Solubility of Gases in Fused Silica." J. Am. Cer. Soc. $49(9): 461$.

Felix, F. W. 1975. "A Nuclear Chemical Method for the Investigation of Argon, Krypton, and Xenon Diffusion in Glasses and Vitreous Silica." Glastech. Ber. $45(10): 213$.

Perkins, W. G. and D. R. Begeal. 1971. "Diffusion and Permeation of He, $\mathrm{Ne}, \mathrm{Ar}, \mathrm{Kr}$, and $\mathrm{D}_{2}$ Through Silicon Oxide Thin Films." J. Chem. Phys. $54(4): 1683$.

Shelby, J. E. 1973. A Comprehensive Review of Gas Permeation, Diffusion, and Solubility in Inorganic Glasses. SLL-73-0259, National Technical Information Service, Springfield, Virginia.

Thamer, B. J., C. M. Mihlfeith, and P. J. Macbeth. 1979. The Evaluation of Alternatives for Ultimate Disposal of Krypton-85, Task 1-A Compilation of ATternatives. UC-261-01, Ford, Bacon, and Davis, Utah, Inc.

Tingey, G. L., E. D. McClanahan, M. A. Bayne, and R. W. Moss. 1979. Entrapment of Krypton in Sputter Deposited Metals - A Storage Medium for Radioactive Gases. PNL-2879, Pacific Northwest Laboratory, Richland, Washington.

U.S. Environmental Protection Agency. "Environmental Radiation Protection Standards for Nuclear Power Operations," 42 Fed. Reg. No. 9, Title 40, Part 190 (1977). 
Walker, Jr., P. L., L. G. Austin, and S. P. Nandi. 1966. "Activated Diffusion of Gases in Molecular Sieve Materials." In Chemistry and Physics of Carbon, Vol. 2, ed. P. L. Walker, Jr., p. 292. Marcel Dekker, Inc., New York. 


\section{DISTRIBUTION}

No. of

Copies

A. A. Churm

DOE Chicago Patent Group

9800 South Cass Avenue

Argonne, IL 60439

J. D'Ambrosia

DOE Nuclear Waste Management

Washington, DC 20545

G. H. Daly

DOE Nuclear Waste Management

Washington, DC 20545

G. Ortel

DOE Nuclear Waste Management

Washington, DC 20545

A. F. Perge

DOE Nuclear Waste Management

Washington, DC 20545

W. C. Remini

DOE Advanced Systems and

Materials Production Division

Washington, DC 20545

J. B. Whitsett

DOE Idaho Operations Office

P.0. Box 2180

Idaho Fal 1s, ID 83401

27 DOE Technical Information Center

J. Christian

Exxon Nuclear Idaho Co.

550 Second Street

Idaho Falls, ID 83401

R. A. Brown

Exxon Nuclear Idaho Co.

550 Second Street

Idaho Falls, ID 83401
No. of

Copies

R. E. He ineman

Battelle Project Management Division

Battelle Memorial Institute 505 King Avenue

Columbus, $\mathrm{OH} 43201$

R. D. Klett

Sandia Laboratories

Albuquerque, NM 87115

D. A. Knecht

Exxon Nuclear Idaho Co.

550 Second Street

Idaho Falls, ID 83401

J. Tanner

Exxon Nuclear Idaho Co.

550 Second Street

Idaho Falls, ID 83401

H. Peterson

NRC Office of Standards and Development

Washington, DC 20555

W. W. Brandt

Department of Chemistry

University of Wisconsin

Milwaukee, WI 53201

B. J. Thamer

Ford, Bacon, and Davis

P. 0. Box 8009

Salt Lake City, UT 84018

ONSITE

DOE Richland Operations Office

P. A. Craig

H. E. Ransom

M. J. Zamorski 
No. of

Copies

40 Pacific Northwest Laboratory

T. D. Chikalla

R. L. Dijlon

H. R. Gardner

W. J. Gray

C. R. Hann

P. E. Hart

L. T. Lakey

J. M. Lytle (5)

E. D. McClanahan
No. of

Copies

J. L. McETroy

D. E. Olesen

A. M. Platt

R. P. Raney

G. L. Tingey (10)

R. P. Turcotte

K. R. Wheeler (5)

Technical Information (5)

Publishing Coordination 